Humaniora. Czasopismo Internetowe

Nr 1 (33)/2021, ss. 33-47

\author{
KS. MAREK SOŁTYSIAK \\ Uniwersytet Papieski Jana Pawła II w Krakowie \\ Wydział Filozoficzny, Katedra Filozofii Poznania \\ e-mail: marek.soltysiak@upjpz.edu.pl \\ ORCID: 0000-0003-4437-0321 \\ DOI: https://doi.org/10.14746/h.2021.1.2
}

\title{
De revolutionibus Mikołaja Kopernika a doktryna podwójnej prawdy
}

\begin{abstract}
The presented article is an attempt to answer the question: whether Copernicus in De revolutionibus did not preach the doctrine of double truth? In the first part it is pointed out that the thesis he adopted about the real character of the Earth movement is contrary to the scholastic principles of philosophy and theology. From this point of view, it is exposed to the above allegation. The second part of the article shows the strategy adopted by Copernicus to avoid suspicion of proclaiming the double truth. He defined the basic principles of the new science. He has adopted the mathematical structure of the world. He synthetically linked the movements of all planets due to the movement of the Earth. He showed the coherence of the heliocentric system with the biblical arguments.
\end{abstract}

Keywords: Nicolaus Copernicus, heliocentric system, doctrine of double truth

\section{Wstęp}

$\mathrm{D}$ oktryna podwójnej prawdy ${ }^{1}$ stała się w nowożytności jednym z najbardziej dyskutowanych problemów za sprawą dzieła Mikołaja Kopernika (1473-1543)

${ }^{1}$ Problematyka doktryny podwójnej prawdy kładzie się cieniem na relacje nauki do teologii od 1277 r., kiedy to biskup Paryża Stephen Tempier wydał dekret potępiający 219 tez. Por. J.F. Wippel, The Parisian Condemnations of 1270 and 1277, w: A Companion to Philosophy in the Middle Ages, ed. J.J.E. Gracia, T.N. Noone, Blackwell Publishing, Malden-Oxford-Melbourne-Berlin 2002, s. 65. 
De revolutionibus (1543)². Przez ponad sześćdziesiąt lat opus vitae astronoma z Fromborka nie wzbudzało większych sporów. Dopiero na początku XVII wieku, szczególnie na skutek zaangażowania się Galileo Galilei - Galileusza (1564-1642) w obronie kopernikanizmu, stało się ono przedmiotem licznych kontrowersji ${ }^{3}$. Galileusz w listach kopernikańskich ${ }^{4}$ określił na nowo relację pomiędzy nauką a teologią, a w szczególności pomiędzy astronomią a Biblią. Jego zaangażowanie po stronie Kopernika doczekało się obszernych opracowań, jako tzw. pierwsza i druga sprawa Galileusza ${ }^{5}$. Był on świadom tego, iż obrona kopernikanizmu jako rzeczywistego obrazu świata naraża go na zarzut głoszenia podwójnej prawdy ${ }^{6}$. Podczas drugiego procesu przed Inkwizycją w 1633 roku przytoczył słowa kardynała Roberta Bellarmina (1542-1621), który przestrzegł go w lutym 1616 roku, „iż pogląd Kopernika, rozumiany dosłownie jest sprzeczny z Pismem Świętym, nie należy go głosić ani bronić, ale że można było się nim posługiwać jedynie jako hipotezą”7.

${ }^{2}$ Por. M. Kopernik, O obrotach, tłum. M. Brożek, St. Oświecimski, w: idem, Dzieła wszystkie, t. 2, PWN, Warszawa- Kraków 1976. Przegląd różnych stanowisk interpretacyjnych twórczości Kopernika zawiera praca M. Kokowskiego, Różne oblicza Mikołaja Kopernika. Spotkania z historiq interpretacji, Instytut Historii Nauki PAN, Warszawa-Kraków 2009. Chronologię wydarzeń związanych z życiem i twórczością astronoma z Fromborka przedstawiają prace: M. Biskupa, Regesta Copernicana, Studia Copernicana, t. VII, Ossolineum, Wrocław-Warszawa-Kraków-Gdańsk 1973 oraz J. Sikorskiego, Mikołaj Kopernik na Warmii, chronologia życia i działalności, w: Kopernik na Warmii. Życie i działalność publiczna. Działalność naukowa. Środowisko. Kalendarium, red. J. Jasiński, B. Koziełko-Poklewski, J. Sikorski, Stacja Naukowa Polskiego Towarzystwa Historycznego (Instytut Mazurski), Ośrodek Badań Naukowych im. Wojciecha Kętrzyńskiego, Olsztyn 1973, ss. 427-520. Nieoceniony wkład w poznanie jego twórczości mają prace Ludwika A. Birkenmajera, w tym jego monografia Mikołaj Kopernik. Część pierwsza. Studya nad pracami Kopernika oraz materyały biograficzne, Akademia Umiejętności, Kraków 1900 oraz Aleksandra Birkenmajera, Mikołaj Kopernik: dzieło wielkiego astronoma, „Kwartalnik Historii Nauki i Techniki” 1973, XVIII, nr 3, ss. 451-461. Z prac obcojęzycznych pomocne w opracowaniu tematu artykułu były prace E. Rosena, Three Copernican Treatises. The Commentariolus of Copernicus. The Letter against Werner. The Narratio prima of Rheticus, Octagon Books, New York 1971 oraz A. Koestlera, The sleepwalkers. A history of man's changing vision of the universe, The Macmillan Company, New York 1959.

${ }^{3}$ Por. M. Sołtysiak, Próba przezwyciężenia doktryny podwójnej prawdy przez Galileusza, „Humaniora. Czasopismo Internetowe” 2019, 4(28), ss. 17-38.

${ }^{4}$ List do o. Benedetto Castellego z 21 grudnia 1613 roku; dwa Listy do Mons. Piero Diniego z 16 lutego 1615 i z 23 marca 1615 roku oraz List do Wielkiej Księżnej Krystyny Lotaryńskiej z 1615 roku. Por. Galileo Galilei, Listy kopernikańskie, tłum. T. Sierotowicz, A. Adamski, Biblos, Tarnów 2006.

${ }^{5}$ Por. Dokumentacja procesu Galileusza, tłum. M. Olszańska, K. Sławińska, A. Szostkiewicz, w: Sprawa Galileusza, red. J. Życiński, Wydawnictwo Znak, Kraków 1991, ss. 89-115; A. Fantoli, Galileusz. Po stronie kopernikanizmu i po stronie Kościoła, tłum. T. Sierotowicz, „Studia Galileiani” t. 6, Biblos, Tarnów 2002; The Church and Galileo, red. E. McMullin, University of Notre Dame Press, Notre Dame, Indiana 2005.

${ }^{6}$ Por. Galileo Galilei, List do Benedetto Castellego, s. 35 oraz idem, List do Wielkiej Księżnej, ss. 62, 66-67.

${ }^{7}$ Dokumentacja procesu, s. 102. 
Problem astronoma z Fromborka, przed którym kardynał przestrzegał Galileusza, dotyczył dwóch opisów świata: biblijnego i astronomicznego. Według opisu biblijnego Ziemia jest nieruchoma i znajduje się w centrum świata. Wokół niej krążą planety i Słońce. Według systemu heliocentrycznego to wokół nieruchomego Słońca, znajdującego się w centrum świata, krążą planety, a wraz z nimi Ziemia. Bellarmin zaproponował dwie możliwości pogodzenia obu systemów, aby nie pojawiło się niebezpieczeństwo głoszenia podwójnej prawdy. (1) Opisy biblijne dotyczące natury, w tym nieba, należy rozumieć dosłownie. Literalne ich ujęcie ukazuje prawdziwy obraz świata. Astronomia zaś posługuje się tylko użytecznymi hipotezami do obliczeń położeń i ruchu planet. Jej opisy nie przedstawiają realnego obrazu świata. (2) Opisy biblijne dotyczące natury (astronomii) należy interpretować alegorycznie, natomiast hipotezę astronomiczną uznać za prawdziwy obraz świata. Taką możliwość dopuszczał Bellarmin w Liście do o. Foscariniego pod jednym warunkiem: „gdyby zostało udowodnione, że Słońce znajduje się w środku świata, [...] i że Słońce nie krąży wokół Ziemi, lecz Ziemia wokół Słońca”. Tak więc, jego zdaniem, należałoby odrzucić dosłowne rozumienie Biblii. Konieczna byłaby ponowna jej interpretacja „, należałoby wtedy raczej twierdzić, że się Pisma nie rozumie, niż zabieganie o uznanie tego rodzaju dowodu za błąd”8.

Drugie rozwiązanie można byłoby brać pod uwagę pod warunkiem, że ruch Ziemi zostałby udowodniony, a nie tylko zakładany. Problem polega na tym, zdaniem Bellarmina, iż Kopernik takiego dowodu nie przedstawił. Rozumienie zaś jego hipotezy dosłownie, jako prawdziwego obrazu świata, nieuchronnie wikłało się w zarzut głoszenia doktryny podwójnej prawdy.

Kopernik, uważając hipotezę heliocentryczną za rzeczywisty obraz świata, był świadom tych zarzutów ${ }^{9}$. Świadectwem nurtujących go wątpliwości jest jego list do Andreasa Osiandra, astronoma luterańskiego z 1 lipca 1540 roku ${ }^{10}$. List ten jednak zaginął. Dowiadujemy się o nim z relacji Joachima Keplera zawartej w Apologia Tychonis contra Ursum. Był to czas, w którym Kopernik przygotowywał wydanie De revolutionibus i z pewnością list dotyczył problemów z nim związanych. Z udzielonej 20 kwietnia 1541 roku odpowiedzi Osiandra ${ }^{11}$ możemy wywnioskować, że Kopernik prosił o radę, w jaki sposób uniknąć ataków teologów i filozofów w związku z głoszeniem przez niego hipotezy heliocentrycznej ${ }^{12}$.

\footnotetext{
${ }^{8}$ Galileo Galilei, List do o. Paolo Antonio Foscariniego, s. 94.

${ }^{9}$ W swoich pismach nie używał on wyrażenia „podwójna prawda”, lecz mówił o zarzutach filozofów i teologów.

${ }^{10}$ Kepler wspomina o nim: „Nam cum Copernicus anno 1540 Cal. Jul.: ad Osiandrum scripsisset; sic illi inter caetera responder Anno 1541. 20 Apr.” J. Kepler, Apologia pro Tychone contra Ursum, w: The Birth of History and Philosophy of Science: Kepler's A Defence of Tycho against Ursus with essays on its provenance and significance (reprint), ed. N. Jardine, Cambridge University Press, Cambridge 1988, s. 97.

${ }^{11}$ Por. J. Kepler, Apologia, ss. 461-462.

12 Por. M. Biskup, Regesta, s. 200, nr 453.
} 
Osiander zasugerował mu, by wspomniał w przedmowie, iż traktuje głoszone przez siebie hipotezy jako użyteczne narzędzia służące do obliczania położeń planet i gwiazd. Jego propozycja była zgodna z powszechnie stosowaną praktyką w astronomii. Zgodnie z nią występował podział kompetencji pomiędzy astronomią i filozofią naturalną. Astronomia miała „ratować zjawiska”, bez roszczenia sobie prawa co do prawdziwości stosowanych przez siebie hipotez. Filozofia naturalna zajmowała się natomiast przyczynami badanego zjawiska oraz podstawowymi zasadami bytu i poznania. Strategia „ratowania zjawiska” pojawiła się w starożytnej astronomii $^{13}$, była znana w średniowieczu, z powodzeniem została zastosowana w Tablicach Prutenicznych (1551) (Tabulae Prutenicae) przez Erasmusa Reinholda (1511-1553). Kopernik jednak odrzucił propozycję Osiandra rozumienia swej teorii z jej perspektywy.

Dla odpowiedzi na pytanie, czy głosił on doktrynę podwójnej prawdy, interesująca jest zarówno propozycja Osiandra, jak i sytuacja astronoma z Fromborka po jej odrzuceniu. Astronom luterański jest przedstawicielem scholastycznego środowiska teologów i filozofów, których zarzutów Kopernik się obawiał. Jego sugestie zawarte zarówno w listach, jak i w przedmowie Ad Lectorem $^{14}$ do De revolutionibus ukazują „klasyczną” możliwość uchronienia autora przed zarzutem głoszenia doktryny podwójnej prawdy. Zagadnieniu temu zostanie poświęcona pierwsza część artykułu. W następnej części spróbujemy przedstawić następstwa jej odrzucenia. Kopernik musiał przedłożyć przede wszystkim alternatywę dla „starej astronomii” oraz wykazać, iż jego teoria nie stanowi zagrożenia dla autorytetu Biblii. Miała temu służyć napisana przez niego przedmowa do De revolutionibus, czyli List dedykacyjny: „Do Jego Świątobliwości Papieża Pawła III Mikołaja Kopernika Przedmowa do Ksiąg o obrotach”. Przedstawił w nim zasady nowej astronomii związane z matematyczną strukturą świata oraz metodę jego poznania. Ostania część artykułu jest próbą ukazania argumentów Kopernika w przezwyciężeniu zarzutu głoszenia doktryny podwójnej prawdy w związku z głoszeniem przez niego sprzecznych tez odnośnie do ruchu Ziemi w stosunku do tego, co mówi Biblia.

${ }^{13}$ Według Symplicjusza (VI wiek n.e.) zadaniem astronoma nie jest szukanie przyczyn, ale ratowanie zjawisk przez wymyślanie odpowiednich hipotez (fragment z Simplicjusza, In Aristotelii physicorum libros quatuor prioret commeniaria, edidit Hermannus Diels, Berolini, 1882, ss. 291-292, jest przetłumaczony na język francuski: P. Duhem, Sozein ta Phainomena, ss. 9-10; fragment ten jest także tłumaczony na język angielski: T. Heath, Aristarchus of Samos: The Ancient Copernicus, New York-Dover 1981, ss. 275-276). Koncepcja funkcji i roli hipotezy w nauce jako ratowania zjawisk została opracowana przez Pierre’a Duhema. Por. idem, Sozein ta phainomena. Essai sur la Notion de Théorie physique de Platon à Galilée, A. Hermann et Fils, Paris 1908.

${ }^{14}$ Ad Lectorem zostało umieszczone przez Osiandra jako przedmowa do De revolutionibus bez wiedzy i zgody Kopernika. Pełny tytuł przedmowy brzmi: Ad Lectorem de hypothesibus hujus operis (Do czytelnika o zasadach tego dzieła). 


\section{Propozycja Osiandra uniknięcia zarzutu głoszenia doktryny podwójnej prawdy przez Kopernika}

Osiander, w anonimowej przedmowie Ad Lectorem do De revolutionibus, określił cel, jaki stoi przed astronomią. Powinna ona

[...] rekonstruować dzieje ruchów niebieskich na podstawie nieustannej i ścisłej obserwacji, a następnie wymyślić jakiekolwiek ich przyczyny albo hipotezy, jeśli prawdziwych przyczyn w żaden sposób osiągnąć się nie da, i tak powiązać je w całość, żeby na ich podstawie te same ruchy można było trafnie obliczać, według zasad geometrii, zarówno dla przyszłości, jak i dla przeszłości. [...] Nie potrzebują bowiem te hipotezy być prawdziwe, ani nawet zbliżone do prawdy, lecz wystarczy to jedno, że dają obliczenia zgadzające się z obserwacjami ${ }^{15}$.

Astronom, według powyższej propozycji, ma ratować zjawiska, czyli konstruować takie hipotezy, które wytłumaczą ruchy planet i gwiazd oraz ich położenie. Jego obowiązkiem jest dostosowanie odpowiedniej przyczyny do znanego mu skutku. Znając ruch lub spoczynek danego ciała niebieskiego, powinien wymyślić taką przyczynę, która wytłumaczyłaby jego stan w danej chwili. Pojawia się pewna trudność z odnalezieniem tej właściwej przyczyny, ponieważ ten sam fakt (skutek) można zinterpretować na różne sposoby. Nawet fałszywa przyczyna może wyjaśnić obserwowany (prawdziwy) skutek. Niestety astronom nie posiada kryterium, które pozwoliłoby mu rozróżnić fałszywe przyczyny od prawdziwych. Toteż jego hipotezy nie mogą rościć sobie pretensji do bycia prawdziwymi, a nawet prawdopodobnymi.

W związku z tym jedynym źródłem wiedzy pewnej dla luterańskiego astronoma jest to, co Bóg objawił w Piśmie św.: „Filozof będzie może szukał raczej prawdopodobieństwa, lecz ani jeden [filozof - M.S.], ani drugi [astronom - M.S.] nie jest w stanie uchwycić czy podać niczego pewnego, chyba że mu to objawi boskie natchnienie" ${ }^{16}$.

Propozycja Osiandra, aby teorię heliocentryczną uważać za hipotezę ratującą zjawisko, była nie do zaakceptowania dla Kopernika. Po pierwsze, przyjmując ją, musiałby zrezygnować z twierdzenia, iż teoria heliocentryczna przedstawia prawdziwą strukturę świata. Po drugie, musiałby uznać, że teksty biblijne mówiące o bezruchu Ziemi i ruchu Słońca przedstawiają rzeczywisty obraz świata. Obie konsekwencje były sprzeczne z treścią De revolutionibus, co też dostrzegło Święte Oficjum kilkadziesiąt lat później, zarządzając wprowadzenie odpowiednich zmian w jego tekście ${ }^{17}$.

${ }^{15}$ M. Kopernik, O obrotach, s. 327.

${ }^{16}$ Ibidem.

${ }^{17}$ Kongregacja Indeksu opublikowała w 1620 roku dekret, w którym określiła zmiany, jakie należy wprowadzić w tekście De revolutionibus, aby można było z niego swobodnie korzystać. Por. A. Favaro, Galileo e l'Inquisizione. Documenti del processo Galileiano esistenti 


\section{Matematyczna struktura świata}

Kopernik poinformował papieża Pawła III w Liście dedykacyjnym o źródłach powstania systemu heliocentrycznego. Na początku swoich badań astronomicznych zauważył pojawiające się niedokładności, a nawet sprzeczności w teoriach astronomicznych. Przede wszystkim zachowanie planet było niezgodne z koncepcją świata dwusferycznego ${ }^{18}$. Przyjął on hipotezę ruchu Ziemi dla wyjaśnienia trudności pojawiających się w ich obliczeniach. Jego badania astronomiczne mieściły się w ramach ówczesnej metodologii.

[...] zacząłem i ja rozmyślać o ruchu Ziemi. A chociaż taka myśl robiła wrażenie niedorzeczności, jednak - ponieważ wiedziałem, że już innym przede mną przyznawano swobodę wymyślania dowolnych kół dla objaśnienia zjawisk gwiezdnych [jako hipotez ratujących zjawiska - M.S.] - doszedłem i ja do wniosku, że i ja bez przeszkód mam prawo próbować, czy przez przyjęcie jakiegoś ruchu Ziemi nie dałoby się wynaleźć pewniejszych niż tamte sposoby na objaśnienie obrotów sfer niebieskich ${ }^{19}$.

Po przyjęciu hipotezy dotyczącej ruchu Ziemi oraz przez ujęcie ruchów planet ze względu na nią zauważył występującą prawidłowość w badanych przez siebie zjawiskach. Ruchy planet następowały po sobie w określonym porządku, wielkość gwiazd i ruchy ich orbit były tak połączone, że w żadnym przypadku nie można było niczego pominąć bez pomieszania całego układu. Kopernik nie przypuszczał, iż jego początkowe założenie o ruchu Ziemi, które było jedynie przyjętą przez niego hipotezą roboczą, może być rzeczywistym obrazem świata.

Synchroniczna całość ruchu planet i gwiazd, która ujawniła się w systemie heliocentrycznym, wykraczała poza dotychczasowe rozumienie hipotezy w astronomii. Nie była ona ani dowolna, ani przypadkowa, tzn. nie można jej było zastąpić inną hipotezą. Okazała się konieczna. Doszedł do przekonania, iż wszechświat ujęty matematycznie, z poruszającą się Ziemią oraz z ruchami pozostałych planet analizowanymi ze względu na jej ruch, jest jedynym możliwym systemem i dlatego jest prawdziwy ${ }^{20}$.

Co zatem się wydarzyło w jego pracy naukowej, że ruch Ziemi zaczął traktować nie jako użyteczną hipotezę, lecz jako rzeczywistość? Na początku założył, że Ziemia się porusza, a Słońce jest nieruchome i znajduje się w centrum świata. W tym punkcie swoich rozważań był w zgodzie zarówno z Ptolemeuszem, jak i ze współczesnymi mu astronomami, którzy przyjmowali różne hipotezy tłumaczące zjawiska. W odróżnieniu od nich jednak, po pierwsze, rozważał zachowanie planet i gwiazd

nell' Archivio del S. Uffizio e nell'Archivio Segreto Vaticano, G. Barbèra Editore, Firenze 1907, ss. $140-141$.

${ }^{18}$ Por. ibidem.

${ }_{19}$ M. Kopernik, O obrotach, s. 5.

${ }^{20}$ Ibidem. 
ze względu na ruch Ziemi. Po drugie, analizował zachowanie konkretnej planety w powiązaniu z ruchami innych planet i gwiazd, a nie jak dotychczas „punktowo”, niezależnie od nich. Po trzecie, podkreślił wyjątkową rolę matematyki w swoich badaniach. Wykroczył poza przypisane jej zadanie w astronomii arystotelesowsko-ptolemeuszowej, obliczenia ruchu czy określenia pozycji pojedynczych planet ${ }^{21}$. Porzucił arystotelesowsko-scholastyczne rozumienie matematyki i jej roli w astronomii. Zarówno on, jak i nieliczni jego zwolennicy działający w drugiej połowie XVI wieku uważali się za platoników ${ }^{22}$. Kopernik podczas studiów we Włoszech (1496-1503) zapoznał się z filozofią neoplatońską. Szczególny wpływ na niego miał boloński profesor astronomii Dominik Maria Novara (1454-1504) ${ }^{23}$. Jako jeden z pierwszych astronomów skrytykował planetarną teorię Ptolemeusza. Uważał, że jest ona zbyt skomplikowana, aby mogła ukazać matematyczny porządek przyrody ${ }^{24}$. W podobnym neoplatońskim tonie wypowiedział się Kopernik w Liście dedykacyjnym o astronomach, którzy podążając za wskazaniami Ptolemeusza, przyjęli zasady, „które stoją w oczywistej sprzeczności z podstawowymi zasadami jednostajności ruchu. Nie zdołali też odkryć albo z nich wyprowadzić rzeczy najważniejszej, mianowicie układu wszechświata i ustalonego porządku jego części”25. Pogląd Kopernika dotyczący matematycznej budowy wszechświata jest nie tylko zgodny z filozofią neoplatońską, ale również z myślą pitagorejczyków i stoików. Według ich koncepcji wszechświat stanowi koherencyjny system planet i gwiazd, a nie zlepek niepowiązanych ze sobą części. Przypisali matematyce rolę nie do pomyślenia dla arystotelików ${ }^{26}$. Wierzyli, że natura ma zasadniczo matematyczną strukturę. Według astronoma z Fromborka to matematyka, a nie filozofia naturalną, ujawnia prawdziwą strukturę układu planetarnego i przedstawia rzeczywisty obraz świata ${ }^{27}$.

Dla Georga Joachima Rheticusa-Retyka (1514-1574) koherencyjny charakter modelu Kopernika jest znakiem jego prawdziwości: „Wszystkie [...] zjawiska w sposób widoczny są niby złotym łańcuchem przepięknie ze sobą powiązane. Każda planeta swoim położeniem, swym układem i wszelką zmianą swojego ruchu

${ }^{21}$ „Świat fizyczny nie jest światem geometrycznej ścisłości, lecz światem zmysłowych jakości - tego, co można poznać tylko zmysłami. Arystoteles sformułował nawet coś w rodzaju reguły zakazującej matematyki do opisu rzeczywistości (zwanej regułą metabasis)”. M. Heller, Nowa fizyka i nowa teologia, Biblos, Tarnów 1992, ss. 46-47.

${ }^{22}$ Michał Kokowski przedstawia różne, często przeciwstawne interpretacje stanowiska Kopernika dotyczące jego stosunku zarówno do filozofii pitagorejczyków, jak i Platona i Arystotelesa. Por. M. Kokowski, Różne oblicza Mikołaja Kopernika.

${ }^{23}$ Por. L.A. Birkenmajer, Mikołaj Kopernik, ss. 424-438.

${ }^{24}$ Por. Th.S. Kuhn, Przewrót kopernikański, tłum. S. Amsterdamski, Prószyński i S-ka, Warszawa 2006, s. 156.

${ }^{25}$ M. Kopernik, O obrotach, s. 4.

${ }^{26}$ Por. Th.S. Kuhn, Przewrót, s. 171.

${ }^{27}$ Por. M. Kopernik, O obrotach, ss. 5-6. Kopernik wprowadził ważną innowację w nauce - podporządkował fizykę (filozofię naturalną) astronomii. Odwrócił tym samym starożytną i średniowieczną tradycję. 
poświadcza ruch Ziemi”²8. Trojaki ruch przypisany Ziemi ${ }^{29}$ wytworzył symetrię we wszechświecie. Retrogradacje i postępy planet zostały uczynione fizycznie zrozumiałe. Konsekwencje ruchu Ziemi odegrały kluczową rolę w przekonaniu Kopernika, iż Ziemia naprawdę się porusza ${ }^{30} \mathrm{i}$ że jego hipoteza jest prawdziwym odzwierciedleniem rzeczywistości kosmologicznej ${ }^{31}$.

\section{Nowa metoda w nauce}

Astronomia teoretyczna za czasów Kopernika była w głębokim kryzysie. Mechanizm ruchów ciał niebieskich przedstawiany przez astronomów stawał się coraz bardziej skomplikowany i nieprzejrzysty, a równocześnie wzrastała rozbieżność między ich obliczeniami. Podczas gdy jedni przyjmowali określoną „poprawkę” czy „uzupełnienie”, to drudzy ją odrzucali i wprowadzali inną. Obserwacje raz po raz wykazywały niezgodność tablic astronomicznych z układem gwiazd i planet ${ }^{32}$. Kopernik w Liście dedykacyjnym stawia diagnozę tego stanu rzeczy. Według niego naukowcy „,w toku swych dowodów, czyli w tzw. metodzie, albo opuścili coś koniecznego, albo też przyjęli coś obcego, co zgoła do rzeczy nie należy. A byłoby się im to z pewnością nie przydarzyło, gdyby się trzymali pewnych zasad zdecydowanie. Bo gdyby przyjęte przez nich założenia nie były zwodnicze, ponad wszelką wątpliwość musiałyby się sprawdzić również wszystkie wypływające z nich wnioski”33.

Kopernik, już jako student ${ }^{34}$, zauważył brak logicznej konsekwencji „trzymania się pewnych zasad” w systemie Ptolemeusza. Rozważane przez niego w Almageście ruchy koliste nie były tak naprawdę ruchami jednostajnymi po kole, lecz tylko ruchami „pozornie jednostajnymi” ${ }^{35}$. Ta niespójność, jak pisze w Commentariolusie, była przyczyną odrzucenia systemu Ptolemeusza przez niego:

Atoli mechanizm przyjęty przez Ptolemeusza, a następnie także przez wielu innych, jakkolwiek liczbowo zgadzał się ze zjawiskiem na niebie, niemałe jednakże obudzał wątpliwości. Twórcy tego urządzenia zdołali bowiem rzecz ową tylko w ten sposób

${ }^{28}$ Retyk, Relacja pierwsza, ss. 118-119.

${ }^{29}$ Por. M. Kopernik, O obrotach, ss. 23-26.

${ }^{30}$ Por. ibidem, s. 12.

${ }^{31}$ Kopernik stwierdza, iż „wszystko w nich ustanowione jest w najlepszym ładzie i boską kierowane wolą” (O obrotach, s. 7). Konkretne cytaty fragmentów, w których Kopernik opisuje ruch Ziemi, por. E. Rosen, Three Copernican, ss. 30 i 93.

${ }^{32}$ Por. A. Birkenmajer, Mikołaj Kopernik, ss. 455-456.

${ }_{33}$ M. Kopernik, O obrotach, s. 4.

${ }^{34}$ Por. M. Kopernik, Zarys nowego mechanizmu świata i ruchów ciał niebieskich (Commentariolus), w: idem, Wybór pism w przekładzie polskim, tłum. L.A. Birkenmajer, Druk W.L. Anczyca i Spółki, Kraków 1920, s. 35.

${ }^{35}$ Por. Ptolemaeus Claudius, Almagest (Ptolemy’s Almagest), tłum. G.J. Toomer, Duckworth, London 1984, ss. 136-172, por. A. Birkenmajer, Mikołaj Kopernik: dzieło wielkiego astronoma, s. 455. 
dostatecznie wytłumaczyć, że musieli wprowadzić pewne koła fikcyjne, nazwane ekwantami, według których planeta ani w swoim kręgu unoszącym, ani też w odniesieniu do własnego środka nie poruszała się jednostajnie. Dlatego to tego rodzaju pomysł wydawał się nie dość bezpieczny i nie wytrzymujący rozumowego probierza ${ }^{36}$.

Nowa metoda w astronomii, według jego koncepcji, powinna charakteryzować się prawdziwością swoich hipotez. W związku z tym powinny one spełniać podwójne kryterium. Po pierwsze, powinny ocalać zjawiska, tzn. wydedukowane z nich wyniki powinny być zgodne z zaobserwowanymi zjawiskami. Po drugie, powinny zgadzać się z fundamentalnymi założeniami astronomii. System Ptolemeusza spełniał pierwszy warunek, lecz mimo to został odrzucony zgodnie z zasadami tej metody, ponieważ naruszył drugi. Złamał aksjomat jednorodności ruchu ${ }^{37}$.

Hipoteza ruchu Ziemi w systemie heliocentrycznym była, zdaniem Kopernika, podstawową hipotezą, która spełniała ten podwójny wymóg. Nazwał ją naczelnym założeniem astronomii (principio / hypothesi) ${ }^{38}$. Oprócz niej przyjął w swoim systemie cztery hipotezy, które stanowiły podstawowe jego zasady.

Przytoczyłem pokrótce te wiadomości z nauk przyrodniczych, które uważałem za nieodzowne dla naszego przedmiotu jako zasadnicze założenia, a mianowicie, (1) że świat jest kulisty, niezmierzony i podobny do nieskończonego, (2) a także, że wszystko w sobie zawierająca sfera gwiazd jest nieruchoma, (3) wszystkie zaś inne ciała niebieskie poruszają się po kołach; (4) założyłem również, że Ziemia porusza się pewnymi ruchami kolistymi. To wszystko stanowi niejako fundament, na którym usiłuję zbudować całą astronomię. Dowodzenia zaś, którymi będę się posługiwać prawie w całym dziele, dotyczą linii prostych, łuków oraz trójkątów płaskich i sferycznych ${ }^{39}$.

Główne zasady astronomii Kopernik przejął z filozofii perypatetycko-scholastycznej. Należą do nich: świat sferyczny otoczony nieruchomą sferą gwiazd stałych; planety, zgodnie z aksjomatem Platona, poruszają się po okręgach. Do nich należy dodać doktrynę o czterech elementach i związanych z nimi ruchach przyrodzonych oraz o naturalnym miejscu każdego z nich. Ruch Ziemi, chociaż zgodnie z aksjomatem Platona, odbywa się po okręgu, to jednak wykracza poza zastany schemat świata dwusferycznego i dezaktualizuje go. „Nowy świat” Kopernika zbudowany jest z ,linii prostych, łuków oraz trójkątów płaskich i sferycznych”. Jest to świat matematyki.

Olaf Pedersen i Mogens Pihl, analizując system heliocentryczny Kopernika, doszli do wniosku, iż nie był on wynikiem nowego doświadczenia, tylko konstrukcją teoretyczną opartą na trzech fundamentalnych zasadach ${ }^{40}$. Po pierwsze,

36 M. Kopernik, Zarys nowego mechanizmu świata, ss. 34-35.

37 Por. M. Kopernik, O obrotach, s. 4.

38 Por. ibidem, s. 26.

39 Ibidem.

40 Por. O. Pedersen, M. Pihl, Early Physics and Astronomy: A Historical Introduction, Macdonald \& Co, New York 1974, s. 303. Jego trzy aksjomaty są odzwierciedleniem siedmiu 
na metafizycznej zasadzie doskonałości ruchu kołowego wynikającego z natury kuli $^{41}$. Po drugie, na matematycznej zasadzie możliwości rozłożenia każdego ruchu okresowego na szereg jednorodnych ruchów okrężnych ${ }^{42}$. Zgodnie z nim obserwowane ruchy planet i gwiazd należy redukować do jednostajnych ruchów po okręgu. Po trzecie, na epistemologicznej zasadzie - możliwie największej prostocie matematycznej. Zasada ta była zgodna ze scholastycznym poglądem, iż przyroda działa w sposób najbardziej ekonomiczny. Kopernik zatem za pitagorejczykami podkreślił matematyczną prostotę kosmosu ${ }^{43}$.

\section{Warunki zgodności systemu heliocentrycznego z Pismem Świętym}

Nie wszyscy czytelnicy De revolutionibus zdawali sobie sprawę z dokonanej przez Kopernika rewolucji. Dopóki jego dzieło było interpretowane instrumentalnie, tzn. dopóki rozumiane było z perspektywy obowiązującej astronomii, nie dostrzegano jego konfliktu z Biblią. Poruszająca się Ziemia nie przedstawiała rzeczywistego ruchu, ale stanowiła konieczny postulat „ocalenia” zjawisk astronomicznych. Uczeni, którzy przeczytali De revolutionibus z należną uwagą, bez trudu zauważyli, iż Kopernik przedstawia prawdę o wszechświecie. W związku z tym zwrócili uwagę na pojawiające się trudności z pogodzeniem teorii heliocentrycznej z biblijnymi opisami i z ówczesną filozofią naturalną. Biblia wyraźnie stwierdza, iż Ziemia się nie porusza (Psalm 93,1), ale Słońce jest w ruchu (Kohelet 1,4-5; Księga Jozuego 10,12-13). Protestanci i katolicy uznawali niepodważalną prawdę Pisma św. Dla katolików Kościół i tradycja były najwyższymi autorytetami w jego interpretacji. Protestanci przyjęli natomiast zasadę sola scriptura w jego rozumieniu. Sobór Trydencki (1545-1563) przeciwstawił się tej zasadzie ${ }^{44}$.

Kopernik byli świadom występującego napięcia pomiędzy Pismem św. rozumianym dosłownie a głoszonymi przez siebie hipotezami astronomicznymi. Był to klasyczny problem możliwości wystąpienia doktryny podwójnej prawdy. Z pomocą w jego rozwiązaniu przyszedł mu Retyk. Podczas pobytu we Fromborku (1539-1541) napisał on dwie prace. Relację pierwszq ${ }^{45}$, w której przedstawił system

pojedynczych twierdzeń z Commentariolusa. Por. M. Kopernik, Zarys nowego mechanizmu świata, ss. 36-37.

${ }^{41}$ Por. M. Kopernik, O obrotach, s. 16, por. O obrotach, rozdział I, VIII i IX.

${ }^{42}$ Zasada jest matematycznie poprawna, jednak ani Ptolemeusz, ani Kopernik nie znali jej formalnego dowodu.

${ }^{43}$ Ideę tę zaczerpnął z dzieła Plutarcha De placitis philosopharum, gdzie była ona przypisana pitagorejczykom. Por. Kokowski, Różne oblicza Mikołaja Kopernika, s. 318.

${ }^{44}$ Por. Sobór Trydencki, sesja IV, dekret II, tekst polski, w: Breviarum Fidei. Wybór doktrynalnych wypowiedzi Kościoła, red. A. Hartliński, Księgarnia św. Wojciecha, Poznań 1988, s. 117.

${ }_{45}$ Narratio prima wydana została w Gdańsku w roku 1540. Pełny tytuł dzieła brzmi: De libris revolutionum Copernici narratio prima (Relacja pierwsza z ksiąg O obrotach Mikołaja Kopernika). Znana jest jako Narratio prima - Relacja pierwsza. 
Kopernika, oraz drugą, w której poruszał problem zgodności nowej astronomii z Pismem św. O jej istnieniu dowiadujemy się z listu biskupa chełmińskiego Tiedemanna Gisego do Retyka z 26 lipca 1543 roku. Biskup, w reakcji na zniekształcone wydanie norymberskie De revolutionibus, planował opublikować jego poprawioną wersję. W związku z tym proponował Retykowi, aby „dołączył swoje dziełko, w którym trafnie bronił ruchu Ziemi przed niezgodnością z Pismem świętym”46. Niestety „dziełko” to zaginęło, a jego treść pozostała nieznana do drugiej połowy XX wieku. Reyer Hooykaas odnalazł ją w roku $1975^{47}$.

Retyk w pracy zatytułowanej Epistola de terrae motu wypracował podstawowe argumenty obrony heliocentryzmu przed zarzutem jego niezgodności z Pismem św. Powołując się wielokrotnie na autorytet św. Augustyna, przestrzega przed utożsamianiem własnych opinii teologów i filozofów na temat przyrody z autorytetem Biblii $^{48}$. Dla pogodzenia głoszonej przez Kopernika tezy o ruchu Ziemi z Pismem św., zastosował augustiańską zasadę akomodacji. Zgodnie z nią Pismo św. uczy tego, co jest konieczne do zbawienia, natomiast w kwestiach naukowych dotyczących filozofii naturalnej dostosowuje się do codziennych zwyczajów i potocznego sposobu mówienia ludzi ${ }^{49}$. W tym drugim przypadku nie głosi prawdy naukowej.

Kopernik, broniąc się w Liście dedykacyjnym przed zarzutem niezgodności jego teorii z Pismem św., nawiązuje do Epistola Retyka. Krytykuje w nim praktykę powoływania się uczonych na autorytet Biblii w głoszeniu przez nich własnych poglądów, często błędnych ${ }^{50}$.

De revolutionibus jest dziełem matematycznym i to je wyróżnia od innych prac astronomów, kosmologów i filozofów naturalnych. Warunkiem koniecznym jego zrozumienia jest znajomość matematyki. Kopernik zaznacza w Liście dedykacyjnym, iż „Dzieła matematyczne pisane są dla matematyków”51. Dlatego sądu ignorantów w dziedzinie matematyki, dotyczącego jego dzieła, nie bierze pod uwagę i ma w „pogardzie jako lekkomyślny”52. Sama znajomość matematyki w jego

${ }^{46}$ M. Biskup, Regesta, nr 503, s. 220. Por. Sikorski J., Mikołaj Kopernik, nr 567, ss. 518-519.

47 Została ona wydana anonimowo w 1651 roku przez Johannesa van Waesberge’a w Utrechcie pt. Epistola de terrae motu, wraz z dziełem Davida Gorlaeusa Ideaphysicae (1591-1612). Por. R. Hooykaas, Rheticus's Lost Treatise on Holy Scripture and the Motion of the Earth, „Journal for the History of Astronomy” 1984, t. 15, nr 6, ss. 77-80. Edycję krytyczną tekstu wraz z przekładem na j. angielski i argumentami na rzecz autorstwa Retyka zawiera: R. Hooykaas, G.J. Rheticus' Treatise on Holy Scripture and the Motion of the Earth, North-Holland Publishing Co., Amsterdam 1984.

${ }^{48}$ Por. R. Hooykaas, G. J. Rheticus' Treatise, ss. 10, 46, 70.

${ }^{49}$ Por. ibidem, ss. 8, 45, 68

${ }^{50}$ Por. M. Kopernik, O obrotach, s. 5.

${ }^{51}$ Ibidem, s. 6. Pierwsza księga De revolutionibus (ss. 7-49), która jest wprowadzeniem do dzieła, stanowi jedną ósmą całości, a pozostałe pięć ksiąg (ss. 50-324) zawierają szczegółowe obliczenia matematyczne.

${ }^{52}$ Por. M. Kopernik, O obrotach, s. 5. Wprawdzie „lubią [oni - M.S.] bredzić i mimo zupełnej nieznajomości nauk matematycznych roszczą sobie prawo do wypowiadania o nich sądu”, powołując się na autorytet Pisma św. Por. ibidem. 
recepcji jednak nie wystarczy ${ }^{53}$. Kopernik niejako przewidział, iż jego osobiste przekonanie dotyczące stanu fizycznego teorii heliocentrycznej będzie ignorowane przez uczonych. Był świadom możliwości rozumienia jej jako struktury czysto matematycznej. Zawodowi astronomowie korzystali z niej, nie zastanawiając się nad tym, co znajduje się w centrum świata. Ostatecznie i tak wszystkie współrzędne należało przekształcić w geocentryczny układ odniesienia, aby można je było porównać z obserwacjami.

\section{Możliwość poznania prawdy o stworzeniu}

Kopernik był przekonany, iż Bóg objawia człowiekowi prawdę nie tylko w Piśmie św., ale i w swoim stworzeniu (w naturze) ${ }^{54}$. Zwraca uwagę czytelnika na doskonałość stworzonego świata przejawiającą się w jego matematycznej strukturze: „Wszystko to, choć jest trudne i prawie nie do wiary, jako że się sprzeciwia powszechnie przyjętym poglądom, w dalszym ciągu jednak uczynimy, z pomocą bożą, jaśniejszym od Słońca, przynajmniej dla tych, co dobrze znają matematykę" 55. Struktura matematyczna świata, chociaż sprzeczna z jego dotychczasowym rozumieniem przez filozofów i teologów, stała się nieocenioną pomocą w obronie przed zarzutem głoszenia podwójnej prawdy. Był on przekonany, iż ludzki rozum jest w stanie przeniknąć tajemnice stworzenia: „myśli uczonego są niezależne od sądu ogółu - ponieważ dążeniem uczonego, o ile tylko ludzkiemu rozumowi pozwala na to Bóg, jest szukanie we wszystkim prawdy" ${ }^{\text {"56 }}$. Nie przerażały go trudności i zarzuty, na jakie jego poszukiwania były narażone. Jak zaznacza w Liście dedykacyjnym, przeciwstawił się autorytetowi Plutarcha i jego twierdzeniu, iż „ruch gwiazd przekracza wiedzę matematyków”, a następnie dodaje: „spróbuję z pomocą Boga, bez którego niczego zdziałać nie możemy, szerzej te rzeczy zbadać”57.

\section{Zakończenie}

Odpowiedź na pytanie, czy Kopernik w De revolutionibus głosił doktrynę podwójnej prawdy, nie jest prosta. Można spojrzeć na system heliocentryczny przez pryzmat (1) ówczesnej filozofii naturalnej i teologii albo można dokonać jego oceny, biorąc pod uwagę to, co (2) sam astronom z Fromborka przedstawił w swoim dziele i jak próbował ominąć ten zarzut.

\footnotetext{
53 Por. ibidem, s. 5.

54 Por. ibidem, s. 7.

55 Ibidem, s. 21.

56 Ibidem, s. 3.

57 Ibidem, s. 8.
} 
Ad 1 Kopernik świadomie przedstawił swój system jako teorię fizyczną, narażając się na zarzuty ze strony filozofów i teologów głoszenia podwójnej prawdy. Chętnie uznawali oni ruch Ziemi jako dogodne narzędzie w ramach hipotezy ocalającej zjawiska. Odrzucali natomiast jego roszczenie do ukazywania prawdziwej struktury świata. Mimo wysiłków astronoma z Fromborka i jego zwolenników nie udało się im przedstawić wiarygodnych dowodów na ruch Ziemi. Galileusz, po ponad siedemdziesięciu latach od wydania De revolutionibus, został upomniany przez Inkwizycję w roku 1616 za bronienie kopernikanizmu (Listy kopernikańskie), jako prawdziwego obrazu świata, a w roku 1633 roku został potępiony za próbę jej udowodnienia.

Ad 2. Kopernik inaczej rozumiał pojęcie hipotezy ratującej zjawisko niż Osiander, współcześni mu astronomowie, filozofowie i teolodzy. Przedstawiony system w De revolutionibus jest według niego prawdziwą hipotezą ukazującą rzeczywisty obraz świata. Ruch Ziemi, który stanowi fundament systemu, jest ruchem realnym, uzasadnionym metodologicznie. Model heliocentryczny okazał się doskonalszy od modelu geocentrycznego ze względu na wzajemne powiązanie parametrów orbit planetarnych. W systemach ptolemejskich zarówno ruch, jak i położenie każdej planety analizowano osobno, dlatego można było tworzyć w nim alternatywne rozwiązania. Koncepcja Kopernika zaś cechowała się koniecznością, wykluczającą inne modele. Udowodnił on, że jego system jest konieczną hipotezą, dającą całościowy, koherentny obraz ruchu planet ze względu na ruch Ziemi. Rewolucyjny okazał się system matematyczny, za pomocą którego ją przedstawił i uznał za prawdziwą. Ponad autorytet filozofii naturalnej arystotelesowsko-scholastycznej i ówczesnej astronomii postawił autorytet matematyki (astronomii matematycznej) ${ }^{58}$. Opisywał zaobserwowane fakty z taką samą precyzją jak teorie ptolemeuszowskie, a w dodatku jego system był w pewnych aspektach prostszy.

W celu ustrzeżenia się niezgodności głoszonej przez siebie teorii z Pismem św. odwołał się do zasady akomodacji w rozumieniu opisów biblijnych, które odnosiły się do zagadnień naturalnych. Uczynił to niestety bardzo skrótowo, posiłkując się „dziełkiem” Retyka, które pozostało nieznane szerszemu gronu odbiorców. Dla uniknięcia zarzutu o głoszenie doktryny podwójnej prawdy istotne znaczenie miało przyjęcie przez niego matematycznej struktury świata. Bóg będąc Stwórcą całego stworzenia, umożliwił człowiekowi rozumowo przeniknąć i poznać jego budowę. Objawia się człowiekowi zarówno w Biblii, jak i w naturze. Pomiędzy jednym a drugim sposobem ujawniania prawdy nie ma sprzeczności. Jednak w wielu punktach heliocentryczny system Kopernika był niedopracowany i przez to wystawiony na krytykę. Dopiero prace Keplera, Galileusza i Newtona przyczyniły się ostatecznie do przezwyciężenia problemu podwójnej prawdy związanej $\mathrm{z}$ realistycznym rozumieniem teorii heliocentrycznej.

${ }^{58}$ Por. M. Heller, Nowa fizyka, ss. 46-47. 


\section{Literatura}

Birkenmajer A., Mikołaj Kopernik: dzieło wielkiego astronoma, „, Kwartalnik Historii Nauki i Techniki” XVIII 1973, nr 3.

Birkenmajer L. A., Mikołaj Kopernik. Część pierwsza. Studya nad pracami Kopernika oraz materyały biograficzne, Akademia Umiejętności, Kraków 1900.

Birkenmaker A., Dobrzycki J., Komentarz, w: M. Kopernik, O obrotach, tłum. M. Brożek, S. Oświecimski, PWN, Warszawa-Kraków 1976.

Biskup M., Regesta Copernicana, Studia Copernicana, t. VII, Ossolineum, Wrocław-Warszawa-Kraków-Gdańsk 1973.

Duhem P., Sozein ta phainomena. Essai sur la Notion de Théorie physique de Platon à Galilée, A. Hermann et Fils, Paris 1908.

Favaro A., Galileo e l'Inquisizione. Documenti del processo Galileiano esistenti nell' Archivio del S. Uffizio e nell'Archivio Segreto Vaticano, G. Barbèra Editore, Firenze 1907.

Galileo Galilei, Listy kopernikańskie, tłum. T. Sierotowicz, A. Adamski, Biblos, Tarnów 2006.

Breviarum Fidei. Wybór doktrynalnych wypowiedzi Kościoła, red. A. Hartliński, Księgarnia św. Wojciecha, Poznań 1988.

Heller M., Nowa fizyka i nowa teologia, Biblos, Tarnów 1992.

Hooykaas R., G. J. Rheticus' Treatise on Holy Scripture and the Motion of the Earth, North-Holland Publishing Co., Amsterdam 1984.

Hooykaas R., Rheticus's Lost Treatise on Holy Scripture and the Motion of the Earth, „Journal for the History of Astronomy” 1984, t. 15, nr 6.

Kepler J., Apologia pro Tychone contra Ursum, w: The Birth of History and Philosophy of Science: Kepler's A Defence of Tycho against Ursus with essays on its provenance and significance (reprint), ed. N. Jardine, Cambridge University Press, Cambridge 1988.

Koestler A., The sleepwalkers. A history of man's changing vision of the universe, The Macmillan Company, New York 1959.

Kokowski M., Różne oblicza Mikołaja Kopernika. Spotkania z historiq interpretacji, Instytut Historii Nauki PAN, Warszawa-Kraków 2009.

Kopernik M., O obrotach, tłum. M. Brożek, St. Oświecimski, w: idem, Dzieła wszystkie, t. 2, PWN, Warszawa-Kraków 1976.

Kopernik M., Zarys nowego mechanizmu świata i ruchów ciał niebieskich (Commentariolus), tłum. L. A. Birkenmajer, w: M. Kopernik, Wybór pism w przekładzie polskim, tłum. L.A. Birkenmajer, Druk W. L. Anczyca i Spółki, Kraków 1920.

Kuhn Th.S., Przewrót kopernikański, tłum. S. Amsterdamski, Prószyński i S-ka, Warszawa 2006.

Pedersen O., Pihl M., Early Physics and Astronomy: A Historical Introduction, Macdonald \& Co., New York 1974.

Ptolemaeus Claudius, Almagest (Ptolemy’s Almagest), tłum. G.J. Toomer, Duckworth, London 1984.

Retyk J.J., Relacja pierwsza z ksiąg O obrotach Mikołaja Kopernika, tłum. I. Lewandowski, Wydawnictwo Uniwersytetu Warszawskiego, Warszawa 2015. 
Rosen E., Three Copernican Treatises. The Commentariolus of Copernicus. The Letter against Werner. The Narratio prima of Rheticus, Octagon Books, New York 1971.

Sikorski J., Mikołaj Kopernik na Warmii, chronologia życia i działalności, w: Kopernik na Warmii. Życie i działalność publiczna. Działalność naukowa. Środowisko. Kalendarium, red. J. Jasiński, B. Koziełko-Poklewski, J. Sikorski, Stacja Naukowa Polskiego Towarzystwa Historycznego (Instytut Mazurski), Ośrodek Badań Naukowych im. Wojciecha Kętrzyńskiego, Olsztyn 1973.

Sołtysiak M., Próba przezwyciężenia doktryny podwójnej prawdy przez Galileusza, „Humaniora. Czasopismo Internetowe” 2019, nr 4(28).

Wippel J. F., The Parisian Condemnations of 1270 and 1277, w: A Companion to Philosophy in the Middle Ages, red. J.J.E. Gracia, T.N. Noone, Blackwell Publishing, Malden-Oxford-Melbourne-Berlin 2002.

Życiński J., Proces Galileusza - konflikt prawdy i prawa, w: Sprawa Galileusza, red. J. Życiński, Znak, Kraków 1991. 
